\title{
CORPORATE GOVERNANCE DAN PENGUNGKAPAN CORPORATE SOCIAL RESPONSIBILITY PADA PERUSAHAAN GO-PUBLIC DI BURSA EFEK INDONESIA
}

\author{
I Made Sudana (Imadesudana@yahoo.com) \\ Putu Ayu Arlindania W \\ Fakultas Ekonomi dan Bisnis Universitas Airlangga
}

\begin{abstract}
This research investigates the influence of corporate governance toward corporate responsibility disclosure. This research using the proxy of women representation on board, existence of foreign nationalities on board, size of board of independent commissioner as the variable of corporate governance and size, ROE, DER as control variable. The corporate social responsibility disclosure include details of the environment, energy, employee health and safety, employee other, products, community involvement, and general. The sample of this research was extracted with purposive sampling method. The population is the companies listed at Indonesia Stock Exchange. The technique for examining hypothesis is multiple regression analysis. The results indicate that woman on board and DER have a negative non significant effect to corporate social responsibility disclosure. Existence of foreign nationalities on board, size of board of commissioner, size and ROE have a positive significant effect to corporate social responsibility disclosure.
\end{abstract}

Keywords: Corporate Social Responsibility Disclosure, Corporate Governance.

\section{PENDAHULUAN}

Beberapa tahun terakhir telah banyak perusahaan yang menyadari akan pentingnya menerapkan program corporate social responsibility (CSR) sebagai bagian dari strategi bisnis. Penerpan tanggung jawab sosial semakin mendapatkan perhatian oleh kalangan pelaku usaha karena meningkatnya kontrol sosial dan tindakan kritis dari masyarakat. Menurut Gray et al. (1987), tumbuhnya kesadaran publik tentang peran perusahaan di tengah masyarakat melahirkan kritik karena menciptakan masalah sosial, polusi, sumber daya, limbah, mutu produk, tingkat safety produk, serta hak dan status tenaga kerja. Tekanan dari berbagai pihak memaksa perusahaan untuk memberikan tanggung jawab atas dampak aktivitas bisnisnya terhadap masyarakat. Perusahaan dihimbau untuk bertanggungjawab terhadap pihak yang lebih luas dari kelompok pemegang saham dan kreditur saja.

Menurut Guthrie dan Mathews (1985), salah satu informasi yang sering diminta untuk diungkapkan perusahaan saat ini adalah informasi tentang tanggung jawab sosial perusahaan. Tanggung jawab sosial perusahaan tersebut dapat digambarkan sebagai ketersediaan informasi keuangan dan non-kevangan berkaitan dengan interaksi organisasi dengan lingkungan fisik dan lingkungan sosialnya, yang dapat dimuat dalam laporan tahunan perusahaan atau dalam laporan tetang penerapan tanggung jawab sosial yang terpisah.

Sesuai dengan Undang-Undang No.40 tahun 2007 tentang Perseroan Terbatas, disebutkan bahwa perseroan yang bidang usahanya terkait dengan sumber daya alam diwajibkan untuk melaksanakan tanggung jawab sosial dan lingkungan ( Pasal 74 ayat 1). Jika dicermati, peraturan tentang CSR yang relatif lebih terperinci ada pada UU No.19 Tahun 2004 tentang BUMN. Undang-Undang ini kemudian dijabarkan lebih jauh oleh Peraturan Menteri Negara BUMN No.4 Tahun 2007, yang mengatur mulai dari besaran dana hingga tatacara pelaksanaan CSR. Seperti diketahui, CSR milik BUMN adalah Program Kemitraan dan Bina Lingkungan (PKBL). Dalam UU BUMN dinyatakan bahwa selain mencari 
keuntungan, peran BUMN adalah memberikan bimbingan bantuan secara aktif kepada pengusaha golongan lemah, koperasi dan masyarakat.

Corporate social responsibility dapat dilaksanakan secara langsung oleh perusahaan di bawah divisi human resource development atau public relations. Corporate sosial responsibility bisa pula dilakukan oleh yayasan yang dibentuk terpisah dari organisasi induk perusahaan, namun tetap bertanggungjawab kepada CEO atau kepada dewan direksi. Sebagian besar perusahaan di Indonesia menjalankan CSR melalui kerjasama dengan mitra lain seperti LSM, perguruan tinggi atau lembaga konsultan. Meskipun CSR merupakan program yang dianjurkan oleh pemerintah dan terdapat payung hukumnya namun belum semua perusahaan bisa melakukannya, hal ini dapat disebabkan berbagai macam faktor.

Menurut Murwaningsari (2009) CSR memiliki kaitan erat dengan good corporate governance. Seperti dua sisi mata vang, keduanya memiliki kedudukan yang kuat dalam dunia bisnis namun berhubungan satu sama lain. Tanggung jawab sosial berorientasi kepada para stakeholders, hal ini sejalan dengan prinsip-prinsip utama good corporate governance yaitu responsibility, sedangkan pengungkapan pelaksanaan tanggung jawab social perusahaan sejalan dengan prinsip transparansi. Menurut Reksodiputro (2004), konsep corporate social responsibility merupakan bagian pedoman pelaksanaan good corporate governance. Dalam penelitian ini corporate governance diproksikan dengan keberadaan dewan direksi wanita, dewan direksi warga negara asing, dan komposisi komisaris independen.

Penelitian dengan menggunakan komposisi wanita dalam dewan direksi dapat melihat perbedaan kualitas perusahaan dari sudut pandang gender. Selama ini anggota dewan direksi wanita dianggap belum mampu memimpin perusahaan, terkait dengan adanya issu gender. Dalam pandangan umum, wanita dinilai kurang tegas dalam pengambilan keputusan dan cenderung kurang memiliki naluri bersaing. Namun, wanita memiliki sikap kehati-hatian yang tinggi, cenderung menghindari risiko, dan lebih teliti dibandingkan pria. Sisi inilah yang membuat wanita tidak terburu-buru dalam mengambil keputusan. Untuk itu dengan adanya wanita di dalam jajaran direksi, dapat membantu mengambil keputusan yang lebih tepat dan berisiko lebih rendah.

Komposisi dewan direksi warga negara asing dapat melihat hasil dari diversifikasi etnis dalam suatu perusahaan. Dengan adanya dewan direksi warga negara asing, maka perusahaan mampu mengangkat citra perusahaan karena kesan warga negara asing lebih memiliki kompetensi dan profesionalitas di bidangnya.

Komposisi dewan komisaris perusahaan merupakan puncak dari sistem pengelolaan internal perusahaan yang memiliki peranan dalam aktivitas pengawasan. Komposisi dewan komisaris yang besar membuat pengawasan menjadi lebih ketat sehingga perusahaan bertahan hidup, melakukan kegiatan bisnis dan berkembang. Untuk mendukung penelitian dengan proxy di atas, penulis akan menggunakan variabel kontrol rasio profitabilitas dengan proxy return on equity, ukuran perusahaan, dan debt equity ratio.

\section{KERANGKA TEORITIS}

\section{Pengertian dan Pengungkapan Tanggung Jawab Sosial Perusahaan}

Menurut ISO 26000, tanggung jawab social perusahaan (CSR) adalah tanggung jawab sebuah organisasi terhadap dampak dari keputusan-keputusan dan kegiatan-kegiatannya pada masyarakat dan lingkungan, yang diwujudkan dalam bentuk perilaku transparan dan etis, yang sejalan dengan pembangunan berkelanjutan dan kesejahteraan masyarakat, mempertimbangkan harapan pemangku kepentingan, sejalan dengan hukum yang ditetapkan dan norma-norma perilaku internasional, serta terintegrasi dengan organisasi 
secara menyeluruh. Pelaksanaan tanggung jawab sosial perusahaan penting dalam rangka mewujudkan tujuan perusahaan, yaitu meningkatkan nilai perusahaan, dan bagi perusahaan yang telah go public nilai perusahaan akan tercermin pada harga pasar saham.

Pengungkapan kegiatan tanggung jawab sosial yang telah dilaksanakan perusahaan, merupakan salah satu upaya untuk meningkatkan citra perusahaan di masyarakat pada umumnya dan investor pada khususnya. Menurut Mathews (1995), pengungkapan tanggung jawab sosial perusahaan yang sering disebut sebagai social disclosure, corporate social reporting, social accounting merupakan proses mengkomunikasikan dampak sosial dan lingkungan dari kegiatan ekonomi organisasi terhadap kelompok khusus yang berkepentingan dan terhadap masyarakat secara keseluruhan. Hal ini menurut Gray et al. (1987) dalam Sembiring (2005) memperluas tanggung jawab organisasi (khususnya perusahaan), di luar peran tradisionalnya untuk menyediakan laporan keuangan kepada pemilik modal, khususnya pemegang saham.

\section{Indeks pengungkapan corporate social responsibility}

Terdapat beberapa jenis indeks pengungkapan tanggung jawab sosial perusahaan, salah satunya adalah GRI (Global Reporting Index) dari Global Reporting Initiative yang merupakan lembaga untuk mempromosikan standar yang diciptakan dengan memberi arahan bagi perusahaan-perusahaan dalam menerbitkan laporan berkelanjutan tentang tanggung jawab sosialnya. Kerangka pelaporan GRI ditujukan sebagai sebuah kerangka yang dapat diterima secara umum dalam melaporkan kinerja ekonomi, lingkungan dan sosial dari organisasi. Kerangka ini didesain untuk digunakan oleh berbagai organisasi yang berbeda ukuran, sektor, dan lokasinya. Kerangka pelaporan GRI mengandung isi bersifat umum dan sektor yang bersifat spesifik, yang telah disetujui oleh berbagai pemangku kepentingan di seluruh dunia dan dapat diaplikasikan secara umum dalam melaporkan kinerja berkelanjutan dari sebuah organisasi.

Dalam GRI dijelaskan indikator-indikator tentang beberapa kategori CSR, seperti indikator kinerja ekonomi, indikator kinerja lingkungan, praktek tenaga kerja dan pekerjaan yang layak, hak asasi manusia serta tanggungjawab produk. Menurut Ahmad Nurkhin (2007), indicator yang dikemukakan GRI dinilai kurang tepat digunakan dalam penelitian di Indonesia karena item-item dalam kategori GRI cakupannya terlalu dalam dan bersifat khusus, sedangkan di Indonesia kegiatan CSR yang dilakukan masih bersifat umum. Indikator lain yang dapat digunakan untuk mengukur pengungkapan CSR adalah dengan menggunakan item-item yang terdapat dalam jurnal Eddy Rismanda Sembiring tahun 2005, yang menggunakan tujuh kategori yaitu, lingkungan, energi, kesehatan dan keselamatan tenaga kerja, lain-lain tenaga kerja, produk, keterlibatan masyarakat dan umum. Kategori ini diadopsi dari penelitian Hackston dan Milne (1996). Kategori-kategori tersebut lebih cocok diaplikasikan pada kegiatan-kegiatan CSR yang dilakukan oleh perusahaan di Indonesia. Ketujuh kategori tersebut terbagi dalam 90 item pengungkapan.

Berdasarkan peraturan Bapepam No. VIII.G.2 tentang laporan tahunan dan kesesuaian item tersebut untuk diaplikasikan di Indonesia, maka kemudian dilakukan penyesuaian. Dua belas item dihapuskan karena kurang sesuai untuk diterapkan dengan kondisi di Indonesia sehingga tinggal tersisa 78 item pengungkapan. Sekala pengukuran untuk pengungkapan CSR digunakan pengukuran dengan skala nominal (dummy), yaitu setiap item CSR dalam instrument penelitian diberi nilai 1 jika diungkapkan dan nilai 0 jika tidak diungkapkan. Lalu, skor dari setiap item dijumlahkan untuk memperoleh keseluruhan skor untuk setiap perusahaan. 


\section{Corporate Governance}

Definisi corporate governance menurut OECD (Organization for Economic Cooperation and Development), corporate governance merupakan suatu sistem untuk mengarahkan dan mengendalikan perusahaan. Struktur corporate governance menetapkan distribusi hak dan kewajiban di antara berbagai pihak yang terlibat dalam suatu korporasi seperti dewan direksi, para manajer, para pemegang saham dan pemangku kepentingan lainnya. Terdapat beberapa teori yang relevan dengan corporate governance, di antaranya adalah stewardship theory dan agency theory.

Stewardship theory, merupakan teori yang dibangun berdasarkan asumsi filosofis mengenai sifat manusia yang pada hakikatnya dapat dipercaya, mampu bertindak dengan penuh tanggung jawab, memiliki integritas dan kejujuran terhadap pihak lain. Bila asumsi stewardship theory ini diterapkan dalam manajemen perusahaan, maka stewardship theory memandang manajemen sebagai pihak yang dapat dipercaya untuk bertindak sebaikbaiknya bagi kepentingan publik maupun para pemegang saham (shareholders).

Menurut agency theory, perusahaan yang berbentuk perseroan biasanya telah dilakukan pemisahan antara pemilik perusahaan dengan manajer perusahaan. Pemilik atau pemegang saham adalah pihak yang menyertakan modal ke dalam perusahaan, sedangkan manajer adalah pihak yang ditunjuk pemilik dan diberi kewenangan mengambil keputusan dalam mengelola perusahaan, dengan harapan manajemen bertindak sesuai kepentingan pemilik. Karena adanya pemisahan fungsi tersebut, tidak bisa dihindari adanya kemungkinan perbedaan kepentingan. Para manajer dapat bertindak untuk kepentingannya sendiri dalam mengelola perusahaan dan mengabaikan kepentingan pemilik perusahaan. Agar pihak manajemen bertindak sejalan dengan kepentingan pemilik perusahaan, maka dapat dilakukan upaya dengan memberikan insentif yang memadai atau dapat juga dilakukan monitoring dengan mengaudit laporan keuangan perusahaan secara periodik, penunjukan komisaris independen dan sebagainya. Hal ini dimaksudkan agar pihak manajemen dalam mengelola perusahaan dilakukan dengan bertanggungjawab dan transparan.

\section{Prinsip dasar corporate governance}

Terdapat beberapa prinsip dalam implementassi good corporate governance (GCG). Menurut pedoman umum good corporate governance Indonesia, terdapat lima prinsip utama yang terkandung dalam good corporate governance yaitu transparency, accountability, responsibility, independency serta fairness yang akan dijabarkan sebagai berikut :

1. Transparency (keterbukaan informasi), yaitu keterbukaan dalam melaksanakan proses pengambilan keputusan dan keterbukaan dalam mengemukakan informasi materiil dan relevan mengenai perusahaan, termasuk tentang kegiatan CSR .

2. Accountability (akuntabilitas), yaitu kejelasan fungsi, struktur, sistem dan pertanggungjawaban organ perusahaan sehingga pengelolaan perusahaan terlaksana secara efektif.

3. Responsibility (pertanggungjawaban), yaitu kesesuaian di dalam pengelolaan perusahaan dengan prinsip korporasi yang sehat serta peraturan perundangan yang berlaku.

4. Independency (kemandirian), yaitu suatu keadaan di mana perusahaan dikelola secara profesional tanpa benturan kepentingan dan pengaruh atau tekanan dari pihak manajemen yang tidak sesuai dengan peraturan dan perundang-undangan yang berlaku dan prinsip-prinsip korporasi yang sehat.

5. Fairness (kesetaraan dan kewajaran), yaitu perlakuan yang adil dan setara di dalam memenuhi hak-hak stakeholder yang timbul berdasarkan perjanjian serta peraturan perundangan yang berlaku. 


\section{Faktor corporate governance dan pengaruhnya terhadap pengungkapan corporate social responsibility}

\section{Dewan direksi wanita}

Berdasarkan penelitian dari Kramer, Konrad dan Erkut (2006) dalam Lukviarman (2004), menemukan bahwa wanita dapat membuat perubahan di dalam lingkup dewan direksi suatu perusahaan. Adams dan Ferreira (2004) menyatakan kehadiran wanita sebagai dewan direksi dapat memberikan pola tersendiri pada komposisi dewan dan memiliki kecenderungan memberikan hasil yang lebih sukses dibandingkan dengan komposisi dewan direksi yang homogen, selain itu wanita secara inheren dinilai lebih stabil dibandingkan pria. Wanita memakai gaya kepemimpinan kolaboratif, yang dapat memberikan keuntungan dinamis pada dewan direksi dengan peningkatan dalam intensitas mendengarkan inovasi dan keluhan karyawan, dukungan sosial, dan penggunaan strategi win-win solution. Catalyst (2007) menemukan dari perspektif keuangan, rata-rata kinerja finansial perusahaan dengan persentase komposisi wanita dalam dewan direksi yang lebih tinggi memiliki hasil yang baik secara signifikan jika dibandingkan dengan persentase komposisi dewan direksi wanita yang lebih rendah.

Wanita memiliki sikap kehati-hatian yang tinggi, cenderung menghindari risiko, dan lebih teliti dibandingkan pria. Sisi inilah yang membuat wanita tidak terburu-buru dalam mengambil keputusan. Untuk itu dengan adanya wanita di dalam jajaran direksi, dapat membantu mengambil keputusan yang lebih tepat dan berisiko lebih rendah.

\section{Dewan direksi warga negara asing}

Keberadaan warga negara asing dalam komposisi dewan direksi menurut Branco dan Rodrigues (2008) dalam Khan (2010), dapat mengangkat isu kausalitas pengungkapan. Fields dan Keys (2003) juga menemukan bahwa heterogenitas individu-individu dari segi pengalaman, ide, dan inovasi dapat memberikan dampak yang baik pada kinerja perusahaan. Erhardt et al., (2003) berpendapat bahwa representasi etnis dalam dewan direksi dapat meningkatkan kinerja keuangan dari bisnis tersebut. Dalam kaitannya dengan keberadaan anggota dewan direksi warga negara asing akan berdampak positif terhadap pengungkapan kegiatan CSR yang dilaksanakan perusahaan. Hal ini karena warga negara asing yang pada umumnya berasal dari negara yang telah maju dan biasanya memiliki kesadaran dan kepedulian yang tinggi terhadap kondisi lingkungan yang bersih, pendidikan, kesehatan dan sebagainya.

\section{Komposisi dewan komisaris independen}

Tugas utama dari dewan komisaris adalah melakukan pengawasan terhadap perumusan kebijakan dan pelaksanaan kebijakan tersebut oleh direksi dalam menjalankan perusahaan sesuai dengan anggaran dasar serta memberi nasihat kepada direksi. Tugas komisaris sering disebut sebagai business oversight karena menyangkut pemantauan terhadap kemampuan perusahaan untuk bertahan hidup, melakukan kegiatan bisnis dan berkembang. Berkaitan dengan komposisi dewan komisaris dalam suatu perusahaan, Coller dan Gregory (1999) menyatakan bahwa semakin besar jumlah anggota komisaris, maka akan semakin mudah untuk mengendalikan CEO dan monitoring yang dilakukan akan semakin efektif. Jumlah anggota komisaris yang tepat juga bergantung pada sektor industri perusahaan tersebut, karena akan turut menentukan jenis kompetensi yang sebaiknya dimiliki oleh dewan komisaris secara keseluruhan. Ukuran dewan komisaris yang besar akan dapat membuat proses mencari kesepakatan dan proses membuat keputusan menjadi sulit, membutuhkan waktu yang lama dan bertele-tele. Keterbatasan ini perlu diperhatikan dalam menentukan jumlah dewan komisaris. 
Menurut Setyapurnama dan Norpratiwi (2004) dalam Murwaningsari (2009), terdapat tiga elemen penting yang akan mempengaruhi tingkat efektivitas dewan komisaris yaitu independensi, kompetensi dan komitmen. Independensi diharapkan timbul dengan keberadaan komisaris independen. Kompetensi tercipta dengan adanya komite-komite yang dibentuk dewan komisaris, terutama komite audit. Keberadaan komisaris independen dimaksudkan untuk menciptakan iklim yang lebih obyektif, independen, menjaga keterbukaan serta mampu memberikan keseimbangan antara kepentingan pemegang saham mayoritas dan perlindungan terhadap kepentingan pemegang saham minoritas.

\section{Pengaruh faktor lain terhadap pengungkapan corporate social responsibility}

\section{Rasio Profitabilitas}

Menurut Weston dan Copeland (1992), rasio profitabilitas mengukur efektivitas manajemen berdasarkan hasil pengembalian yang dihasilkan dari penjualan dan investasi. Aliran arus kas yang datang adalah hasil dari sejumlah kebijakan dan keputusan. Dengan data historis tentang arus kas dan profitabilitas, diperlukan analisis strategis dan operasi lebih lanjut untuk membuat proyeksi masa depan. Ross et al., (2008) menyatakan bahwa dalam setiap bentuknya, rasio ini dimaksudkan untuk mengukur seberapa efisien perusahaan telah menggunakan aktivanya dan mengolah operasional perusahaan untuk menghasilkan laba.

Secara umum, profitabilitas merupakan pengukuran dari keseluruhan efektivitas dan kinerja badan usaha yang pada akhirnya akan menunjukkan efisiensi dan produktivitas badan usaha. Rasio profitabilitas menjadi salah satu indikator penting dalam proses pengambilan keputusan. Rasio profitabilitas dapat mempengaruhi kebijakan investasi seorang investor. Perusahaan yang mempunyai tingkat profitabilitas tinggi dapat menarik investor untuk menanamkan modalnya di perusahaan tersebut karena menunjukkan keberhasilan kinerja manajemen dalam mengolah operasional perusahaan. Sebaliknya, ketika tingkat profitabilitas perusahaan rendah, maka investor cenderung tidak tertarik untuk menanamkan modalnya bahkan dapat menarik modal yang telah ditanamkan.

Penelitian ini menggunakan ROE karena tujuan perusahaan mengungkapkan tanggung jawab sosial untuk memperoleh keuntungan atau laba demi kelangsungan hidup perusahaan. Hubungan profitabilitas dengan pengungkapan tanggung jawab sosial menurut Danovan dan Gibson (2000), bahwa berdasarkan teori legitimasi, salah satu argumen dalam hubungan antara profitabilitas dan tingkat pengungkapan tanggung jawab sosial adalah bahwa ketika perusahaan memiliki tingkat laba yang tinggi, perusahan menganggap tidak perlu melaporkan hal-hal yang dapat mengganggu kondisi prima perusahaan. Sebaliknya, pada saat tingkat profitabilitas rendah, manajemen berharap para pengguna laporan akan melihat kabar baik dari kinerja perusahaan, misalnya dalam lingkup sosial, dengan demikian investor akan tetap berinvestasi di perusahaan tersebut. Dapat dikatakan bahwa profitabilitas mempunyai pengaruh yang negatif terhadap tingkat pengungkapan tanggung jawab sosial perusahaan.

\section{Ukuran perusahaan}

Ukuran perusahaan digunakan sebagai variabel kontrol karena dikaitkan dengan teori agensi. Perusahaan besar memiliki biaya keagenan yang lebih besar, akan mengungkapkan informasi yang lebih luas untuk mengurangi biaya keagenan tersebut. Perusahaan-perusahaan kecil mungkin tidak menunjukkan perilaku tanggung jawab sosial secara jelas, sebanyak yang dilakukan perusahaan besar, karena perusahaan yang berada dalam tahap dewasa dan tumbuh akan menarik lebih banyak perhatian dari lingkungan perusahaan dan memerlukan respon yang lebih terbuka.

Menurut Cowen et al,. (1987) dalam Sembiring (2005), perusahaan dengan aktivitas operasi yang besar, memiliki pengaruh yang besar di lingkungan perusahaan karena masyarakat 
akan memperhatikan program sosial yang dibuat perusahaan sehingga pengungkapan tanggung jawab sosial akan semakin besar. Dari segi tenaga kerja dengan semakin banyaknya jumlah tenaga kerja dalam suatu perusahaan, maka tekanan pada pihak manajemen untuk memperhatikan kepentingan tenaga kerja akan semakin besar. Program yang berkaitan dengan tenaga kerja merupakan bagian dari tanggung jawab sosial perusahaan, yang semakin banyak dilakukan oleh perusahaan. Hal ini berarti program tanggung jawab sosial perusahaan juga semakin banyak dan akan diungkapkan dalam laporan tahunan.

\section{Debt to equity}

Rasio debt to equity (DER) merupakan bagian dari leverage ratio yang dimaksudkan untuk mengukur berapa besar penggunaan utang dalam pembelanjaan perusahaan dibiayai aktiva. Debt equity ratio mengukur besar kecilnya penggunaan utang dibandingkan modal sendiri perusahaan. Besarnya utang yang terdapat dalam struktur modal perusahaan sangat penting untuk memahami perbandingan antara risiko dan laba yang didapat perusahaan. Perusahaan yang memiliki DER yang tinggi mencerminkan risiko keuangan perusahaan tersebut semakin besar karena utang akan menimbulkan keterikatan yang tetap bagi perusahaan berupa kewajiban untuk membayar beban bunga beserta cicilan kewajiban pokok secara periodik, dibandingkan dengan perusahaan yang rasio DERnya lebih rendah. Sembiring (2005), berdasarkan teori agensi, tingkat penggunaan utang yang tinggi cenderung mengurangi pengungkapan tanggung jawab sosial yang dibuat oleh perusahaan agar tidak menjadi sorotan dari para debtholders.

\section{Hubungan corporate governance dan corporate social responsibility}

Implementasi program CSR oleh perusahaan pada hakikatnya bersifat orientasi dari dalam ke luar. Hal ini berarti sebelum melaksanakan aktivitas CSR yang bersifat discretionary atau voluntary, perusahaan terlebih dahulu harus membenahi kepatuhan perusahaan terhadap hukum. Ruang lingkup tanggung jawab sosial antara lain: a) Basic responsibility yaitu tanggungjawab yang muncul karena keberadaan perusahaan. Contohnya kewajiban membayar pajak, menaati hukum, memenuhi standar pekerjaan dan memuaskan pemegang saham. b) Organizational responsibility, tanggung jawab perusahaan untuk memenuhi kepentingan stakeholder, yaitu karyawan, konsumen, pemegang saham dan masyarakat. c) Societal responsibility, tanggung jawab yang menjelaskan tahapan ketika interaksi antara bisnis dan masyarakat, sehingga perusahaan dapat tumbuh dan berkembang secara berkesinambungan. Semua hal tersebut tidak akan terlaksana dengan baik bila perusahaan tidak menerapkan corporate governance yang baik (GCG).

Dalam Kurihama (2007), perusahaan merasa perlu untuk memperkuat tata kelola perusahaan sebagai upaya untuk mengontrol aspek negatif CSR bagi masyarakat, seperti kecurangan perusahaan, pelanggaran hukum dan peraturan, dan gangguan fungsi normanorma sosial. Corporate social responsibility sebagai fokus tata kelola perusahaan yang akan menjadi alat untuk menggabungkan perhatian para pemangku kepentingan terhadap sosial dan lingkungan kedalam proses pengambilan keputusan bisnis, yang tidak hanya akan bermanfaat bagi investor, tetapi juga pelanggan dan masyarakat (Gill,2008)

\section{MODEL ANALISIS}

Model analisis yang digunakan adalah analisis regresi berganda, yang dirumuskan sebagai berikut:

$$
C S R D l_{i t}=\beta 0+\beta 1 D D W_{i t}+\beta 2 D D A_{i t}+\beta 3 K K l_{i t}+\beta 4 R O E_{i t}+\beta 5 S I Z E_{i t}+\beta 6 D E R_{i t}+e
$$




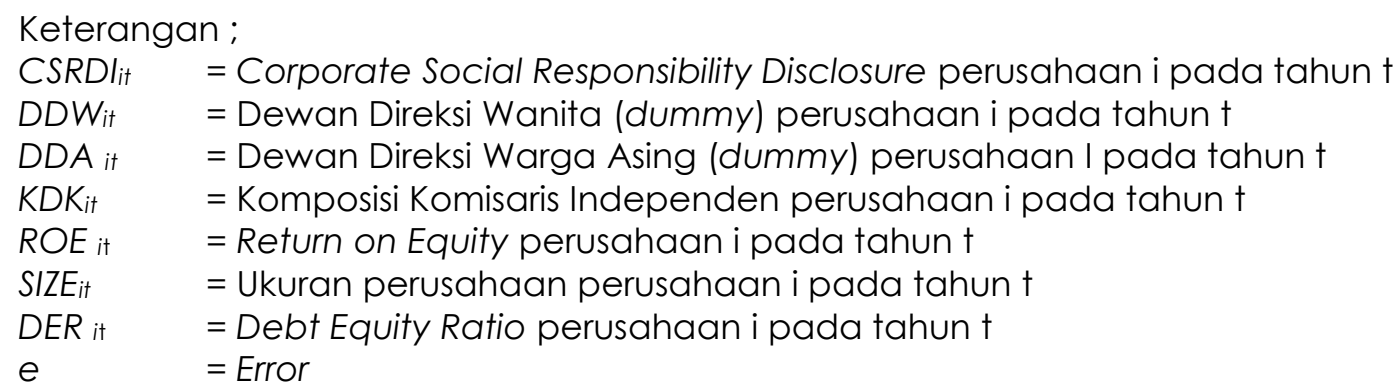

\section{Kerangka Berpikir}

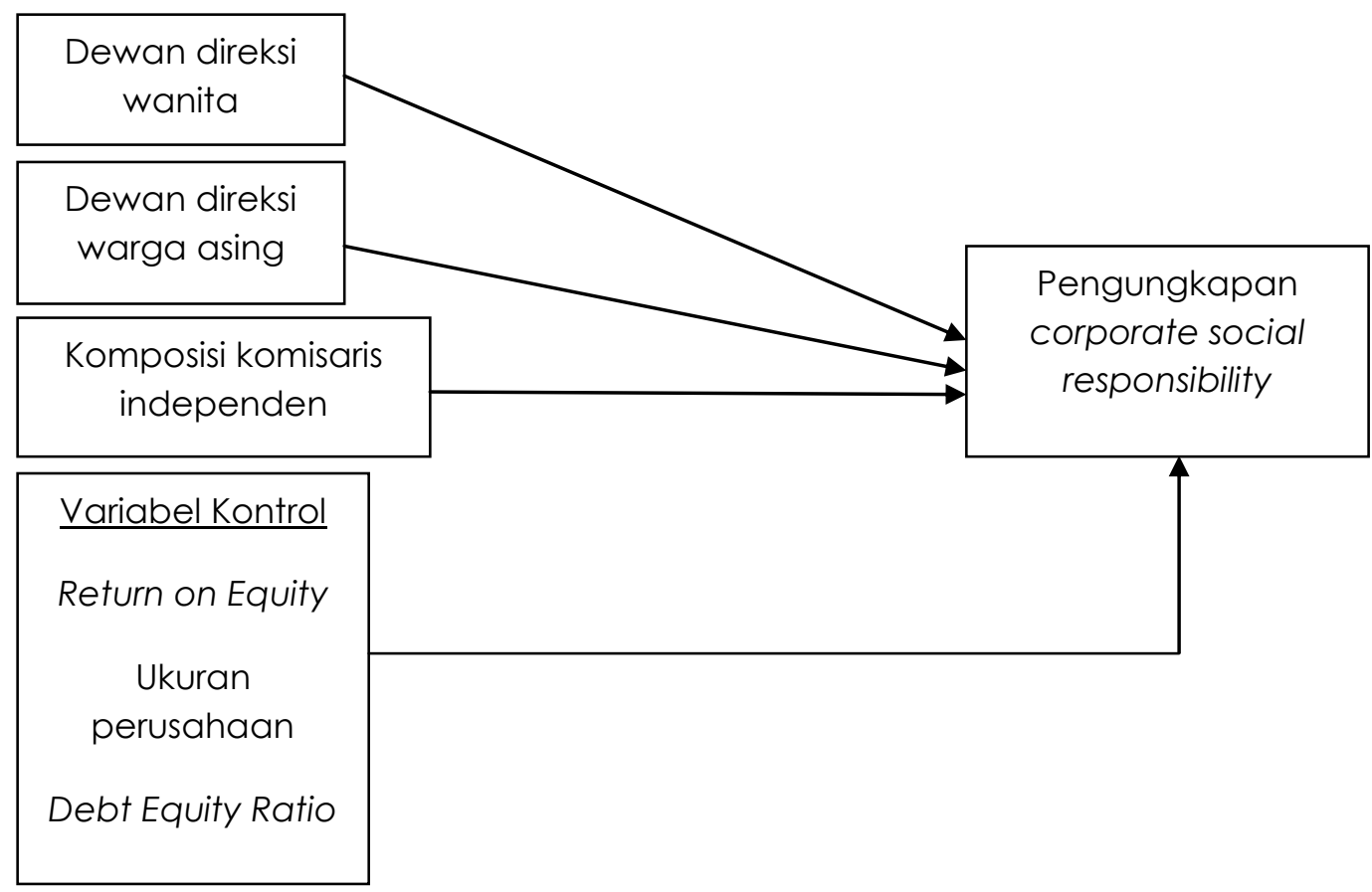

Gambar 1. Kerangka berpikir

\section{Identifikasi Variabel}

Variabel-variabel yang dianalisis dalam penelitian ini adalah :

1. Variabel dependen, yaitu pengungkapan corporate social responsibility

2. Variabel independen yaitu corporate governance, dengan proxy:
a. Dewan direksi wanita
b. Dewan direksi warga negara asing
c. Komposisi komisaris independen

3. Variabel kontrol, yaitu ukuran perusahaan, ROE dan debt equity ratio

\section{Definisi Operasional}

1. Pengungkapan corporate social responsibility (CSRD), merupakan pengungkapan informasi terkait dengan aktivitas tanggung jawab sosial perusahaan. Variabel CSRD diukur dengan persamaan :

$$
\text { CSRDij }=\frac{\Sigma \text { Xij }}{\text { Jumlah item pengungkapan }}
$$




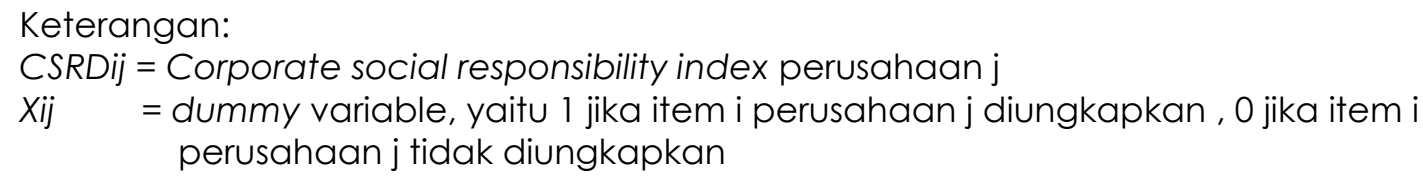

2. Dewan direksi wanita adalah ada tidaknya anggota dewan direksi wanita dalam susunan dewan direksi, yang diukur dengan variabel dummy, yaitu 0 menyatakan tidak ada direksi wanita dalam anggota dewan direksi dan 1 menyatakan ada direksi wanita dalam anggota dewan direksi.

3. Dewan direksi warga negara asing adalah ada tidaknya anggota dewan direksi warga negara asing dalam susunan dewan direksi, yang diukur dengan variabel dummy, yaitu 0 menyatakan tidak ada warga negara asing dalam dewan direksi dan 1 menyatakan terdapat ada warga negara asing dalam anggota dewan direksi.

4. Komposisi komisaris independen, merupakan proporsi dewan komisaris independen di perusahaan, yang diukur dengan jumlah anggota dewan komisaris independen dibagi total anggota dewan komisaris.

5. Ukuran perusahaan, merupakan besar kecilnya perusahaan dalam penelitian ini diukur dengan In total aktiva perusahaan akhir tahun.

Ukuran perusahaan $=$ In total aktiva pada akhir tahun

6. Return on Equity (ROE) menunjukkan kemampuan perusahaan untuk menghasilkan laba setelah pajak dengan menggunakan modal sendiri yang dimiliki perusahaan yang diukur dengan rumus:

Return on equity $(R O E)=\frac{\text { Earning After Taxes }}{\text { Total Equity }}$

7. Debt to Equity (DER), merupakan besar kecilnya penggunaan utang dibandingkan modal sendiri perusahaan.yang diukur dengan persamaan berikut:

Debt Equity Ratio $(D E R)=\frac{\text { Total Debt }}{\text { Total Equity }}$

\section{Prosedur Penentuan Sampel}

Metode yang digunakan dalam penentuan sampel adalah purposive sampling, dengan kriteria-kriteria sebagai berikut :

1. Perusahaan tercatat di Bursa Efek Indonesia periode 2007 - 2009

2. Perusahaan tersebut mengungkapkan kegiatan CSR dalam laporan tahunan untuk periode akuntansi tahun 2007 - 2009 yang dapat diakses melalui website Bursa Efek Indonesia (www.idx.co.id).

\section{ANALISIS DAN PEMBAHASAN}

Dengan menggunakan modal analisis regresi berganda yang telah dikemukakan, hasil analisis yang telah dilakukan diringkas pada tabel berikut. 
Tabel

Ringkasan Hasil Analisis Pengaruh DDW, DDA, KKI, SIZE, ROE DAN DER terhadap pengungkapan CSR

\begin{tabular}{|c|c|c|c|c|c|}
\hline Variabel & Koefisien & Std. Error & $\begin{array}{c}\text { Standardized } \\
\text { Coefficients } \\
\text { Beta }\end{array}$ & $\begin{array}{c}\text { Sig. } t \\
A=0.05\end{array}$ & Kesimpulan \\
\hline DDW & -0.0304 & .022 & -0.108 & 0.176 & Ho diterima \\
\hline DDA & 0.0714 & .023 & 0.248 & $0.002 *$ & Ho ditolak \\
\hline KKI & 0.0017 & .001 & 0.175 & $0.028 *$ & $\mathrm{H}_{0}$ ditolak \\
\hline SIZE & 0.0132 & .006 & 0.175 & $0.031^{*}$ & Ho ditolak \\
\hline ROE & 0.0011 & .000 & 0.229 & $0.003^{*}$ & Ho ditolak \\
\hline DER & -0.0001 & .000 & -0.057 & 0.460 & Ho diterima \\
\hline Constant & & & -0.186 & & \\
\hline R Square & & & 0.255 & & \\
\hline Adj R Square & & & 0.221 & & \\
\hline F hitung & & & 7.631 & & \\
\hline Sig F & & & 0.000 & & \\
\hline Durbin Watson & & & 1.787 & & \\
\hline
\end{tabular}

Sumber : Data yang diolah

Variabel dewan direksi wanita memiliki pengaruh negatif tidak signifikan terhadap pengungkapan tanggung jawab sosial. Hal ini kemungkinan dapat disebabkan oleh faktor budaya di Indonesia, yang mana wanita memiliki sikap mudah mengalah untuk menghargai pria. Hasil analisis data pada perusahaan sampel juga menunjukkan hanya sedikit wanita yang menduduki posisi puncak, sehingga wanita kurang memiliki peranan yang menentukan dalam pengambilan keputusan perusahaan. Selain itu, sebagian besar masyarakat di Indonesia menganut sistem kekerabatan patrilinear (garis keturunan ayah) yaitu bapak memegang kontrol (kendali) atas seluruh anggota keluarga dalam pengambilan keputusan. Hasil penelitian ini berbeda dengan Khan (2010) I yang menyatakan komposisi dewan direksi wanita memiliki pengaruh positif tidak signifikan terhadap pengungkapan tanggung jawab sosial. Bernardi (2010) menyatakan komposisi dewan direksi wanita memiliki pengaruh positif signifikan terhadap pengungkapan tanggung jawab sosial. Dengan argumentasi wanita lebih memiliki komitmen dalam melaksanakan kegiatan amal untuk kesejahteraan masyarakat sekitar perusahaan dibandingkan pria serta kesadaran bahwa pelaksanaan corporate social responsibility memiliki dampak yang baik bagi perusahaan di masa yang akan datang.

Dewan direksi warga negara asing dalam penelitian ini menunjukkan pengaruh positif signifikan terhadap pengungkapan tanggung jawab sosial perusahaan. Hal ini karena warga negara asing di negara asalnya telah lama memiliki perhatian dan kepedulian mengenai aktivitas CSR. Pada saat warga negara asing menjadi anggota dewan direksi di Indonesia, kebiasaan dan sikap dewan direksi asing tersebut memengaruhi keputusan manajemen perusahaan dalam melaksanakan kegiatan CSR dan mengungkapkannya di laporan tahunan perusahaan.

Ukuran dewan komisaris sebagai salah satu faktor dari good corporate governance, yang menggunakan proksi komposisi anggota komisaris independen terhadap total anggota dewan komisaris di perusahaan. Hasilnya menunjukkan adanya pengaruh positif signifikan terhadap pengungkapan tanggung jawab sosial. Hasil ini sesuai dengan tugas dewan komisaris yang bertugas untuk melakukan pengawasan terhadap pengurusan perseroan yang dilakukan oleh direksi. Selain itu kedudukan dewan komisaris independen di perusahaan merupakan perwakilan dari masyarakat sehingga komisaris independen akan mendukung kegiatan-kegiatan perusahaan dalam melaksanakan corporate social responsibility yang dapat meningkatkan kesejahteraan masyarakat sekitar perusahaan dan mengungkapkannya di laporan tahunan perusahaan. 
Teori keagenan menyatakan bahwa semakin besar suatu perusahaan, maka biaya keagenan yang muncul juga akan semakin besar. Untuk mengurangi biaya keagenan tersebut, perusahaan akan cenderung mengungkapkan informasi yang lebih luas. Menurut Gray et al., (1995), perusahaan yang berukuran besar memiliki kemampuan untuk merekrut karyawan yang ahli, serta adanya tuntutan dari pemegang saham dan analis, sehingga perusahaan besar memiliki insentif untuk mengungkapkan informasi CSR lebih luas daripada perusahaan kecil.

Pengaruh profitabilitas pada penelitian ini dengan menggunakan proksi return on equity menunjukkan adanya pengaruh positif signifikan terhadap pengungkapan tanggung jawab sosial perusahaan. Penelitian ini menunjukan bahwa perusahaan yang mempunyai tingkat profitabilitas yang tinggi akan mengungkapkan informasi CSR yang telah dilakukan. Hal ini disebabkan persepsi atau anggapan bahwa aktivitas CSR bukanlah aktivitas yang merugikan dan tidak bermanfaat bagi keberlangsungan perusahaan, melainkan aktivitas CSR yang dapat menjadi langkah strategis jangka panjang yang akan memberikaan efek positif bagi perusahaan dan memberikan citra yang baik bagi pemegang saham.

Debt Equity Ratio merupakan bagian dari leverage ratio yang dimaksudkan untuk mengukur berapa besar penggunaan utang dalam pembelanjaan perusahaan dibiayai aktiva. Dalam penelitian ini debt equity ratio memiliki hubungan negatif tidak signifikan terhadap pengungkapan tanggung jawab sosial perusahaan. Hal ini terkait dengan hubungan antara kreditur dan debitur yaitu perusahaan yang memiliki utang akan mendapat pengawasan dari pihak kreditur. Perusahaan dengan utang yang besar cenderung untuk tidak melaksanakan aktivitas CSR karena pihak kreditur akan lebih menyarankan perusahaan untuk memaksimalkan performa perusahaan agar dapat segera melunasi utangnya kepada pihak kreditur. Kreditur beranggapan bahwa kegiatan CSR akan menghambat kemampuan perusahaan dalam mengembalikan utang, sedangkan perusahaan dengan utang yang kecil akan melaksanakan aktivitas CSR kepada masyarakat sekitar perusahaan.

\section{SIMPULAN}

1. Dewan direksi wanita secara parsial memiliki pengaruh negatif tidak signifikan terhadap pengungkapan CSR, sedangkan dewan direksi asing, komposisi komisaris independen, parsial berpengaruh positif signifikan terhadap pengungkapan CSR.

2. Variabel DDW, DDA, KKI, secara simultan berpengaruh signifikan terhadap pengungkapan CSR perusahaan go-public di Indonesia.

3. Nilai koefisien determinasi $\left(R^{2}\right)$ sebesar 0.255 berarti bahwa sekitar $25.5 \%$ variabilitas besarnya pengungkapan CSR dapat dijelaskan oleh variabilitas variabel yang diteliti, sedangkan $74.5 \%$ dijelaskan oleh variabel lain di luar model.

4. Variabel DDW memiliki pengaruh negatif terhadap pengungkapan CSR, kemungkinan karena wanita di perusahaan Indonesia belum berperan secara optimal dalam pengambilan keputusan mengenai corporate social responsibility karena faktor budaya di Indonesia yang umumnya menempatkan pria memiliki peranan yang lebih besar dalam pengambilan keputusan dibandingkan dengan wanita

5. Variabel DDA memiliki pengaruh positif terhadap pengungkapan CSR, warga negara asing telah memiliki kesadaran dan kepedulian yang tinggi terhadap corporate social responsibility yang di bawa dari negara asalnya.

6. Variabel KKI memiliki pengaruh positif terhadap pengungkapan CSR, dewan komisaris independen sebagai perwakilan dari masyarakat dalam mengawasi kinerja perusahaan, sehingga semakin besar jumlah anggota dewan komisaris independen, maka akan semakin besar pengawasan terhadap keputusan CEO dalam pelaksanaan kegiatan tanggung jawab sosial. 


\section{DAFTAR PUSTAKA}

Adams, R.B. and Ferreira, D. (2004), "Gender diversity in the boardroom", European Corporate Governance Institute, Finance Working Paper No.57

Anggraini, Fr.Reni Retno. (2006). "Pengungkapan informasi sosial dan faktor-faktor yang mempengaruhi pengungkapan informasi social dalam laporan keuangan tahunan (studi empiris pada perusahaan-perusahaan yang terdaftar Bursa Efek Jakarta)".

Bernardi, R. and Threadgill, V. (2010), "Women directors and corporate social responsibility". Electronic Journal of Business Ethics and Organization Studies Vol 10, No.2

Carter, David A., B.J. Simkins, W.G. Simpson.(2003), "Corporate Governance, Board Diversity, and Firm Value", The Financial Review, No.38 pp.33-53

Catalyst.(2007), "Cencus of Women Board Directors of the FP500 : Voices from theBoardroom".

Claessens, S. (2003), "Corporate Governance and Development", Global Corporate Governance Forum, Washington, DC.

Daniri, Achmad. (2008), "Standarisasi Tanggung Jawab Sosial Perusahaan". Dilihat pada 20 Oktober 2010.

Erhardt, N.L., James, D.W. and Charles, B.S, (2003), "Board of director diversity and firm financial performance", Corporate Governance - An International Comparison, Vol. 11 No. 2, pp.102-11.

FGCI. (2001), "Peranan Dewan Komisaris dan Komite Audit dalam Pelaksanaan Corporate Governance". Jilid II. FGCl. Edisi ke-2

Gray, R, Owen, D. and Maunders, K. (1987), "Corporate Social Reporting: Accounting and Accountability", Prentice-Hall, London.

GRI (2002). "Sustainability Reporting Guidelines, Global Reporting Initiative, London. www.globalreporting.org dilihat tanggal 30 September 2010.

Hackston, David and Milne, Marcus J., (1996). "Some Determinants Of Social and Environmental Disclosures In New Zealand Companies", Accounting, Auditing and Accountability Journal, Vol.9, No.1, pp.77-108.

Khan, Md. H.U.Z., (2010), "The effect of corporate governance elements on corporate social responsibility (CSR) reporting", International Journal of Law and Management, Vol.52 No.2, pp.82-109.

Kramer,V.W, Konrad, A.M and Erkut Sumru. (2006). "Critical Mass on Corporate Boards: Why Three or More Women Enhance Governance".

Kusumastuti,S., Supatmi and Sastra P., (2007). "Pengaruh Board Diversity Terhadap Nilai Perusahaan dalam Perspektif Corporate Governance". Jurnal Akuntansi dan Keuangan. Vol.9. No.2. pp. 88-98.

Lukviarman, N. (2004). "Ownership Structure and Firm Performance: The Case of Indonesia". DBA Thesis, Graduate School of Business, Curtin University of Technology, Perth.

Murwaningsari, E., (2009). "Hubungan Corporate Governance, Corporate Social Responsibilities dan Corporate Financial Performance dalam Satu Continuum". Jurnal Akuntansi dan Keuangan, Vol.11 No.3, pp 30-41.

Ross, Stephen A., et al. (2008). "Corporate Finance Fundamentals". New York: McGraw-Hill. Edisi Kedelapan.

Schermerhorn, John R., (1993), "Management for Productivity", New York: John Wiley \& Sons.

Sembiring, Edi Rismanda. (2005), "Karakteristik Perusahaan dan Pengungkapan Tanggung Jawab Sosial: Studi Empiris pada Perusahaan yang Tercatat di Bursa Efek Jakarta". 
Solihin, Ismail. (2008). "Corporate Social Responsibility from Charity to Sustainability". Salemba Empat, pp 115-128.

Sudana, I Made. (2009), "Manajemen Keuangan Teori dan Praktik". Surabaya: Airlangga University Press.

Suryaningsih, Valeny and Lukviarman, N.(2007). "Woman on Board: The Case of Publicity Listed Companies in Indonesia". pp.1-8. 